\title{
Pelayanan Publik Bidang Transportasi bagi Difabel di Daerah Istimewa Yogyakarta
}

\author{
SUGI RAHAYU, UTAMI DEWI, MARITA AHDIYANA \\ Jurusan Ilmu Administrasi Negara FIS UNY \\ e-mail : dewiutamie@yahoo.com
}

\begin{abstract}
Abstrak
Penelitian ini bertujuan menganalisis penyediaan pelayanan publik khususnya bidang transportasi bagi kaum difabel dan mengidentifikasi alternatif solusi yang dapat diterapkan dalam pemberian pelayanan bidang transportasi yang adil dan pro difabel. Penelitian kualitatif dengan metode wawancara, observasi dan dokumentasi. Wawancara kepada dinas terkait yaitu Dinas Sosial, Dinas Perhubungan, dan Dinas Pemukiman dan Prasarana Wilayah serta lembaga-lembaga swadaya masyarakat yang mempunyai perhatian terhadap kaum difabel seperti SIGAB dan SABDA. Data sekunder berasal dari dokumentasi pada dinas-dinas terkait dan media massa serta sumber kepustakaan lain seperti buku dan jurnal. Hasil penelitian menunjukkan bahwa penyediaan layanan perhubungan untuk memenuhi kebutuhan kaum difabel belum optimal. Pemerintah Kota Yogyakarta menyediakan fasilitas perhubungan ramah difabel, Sleman menyediakan trotoar ramah difabel khususnya di sekitar kompleks perkantoran pemerintah daerah. 3 kabupaten lain belum optimal dalam penyediaan fasilitas.
\end{abstract}

Kata kunci: pelayanan publik, difabel, transportasi, DIY

\begin{abstract}
This research aims to analyze the provision of public services particularly in the field of transportation for disabled people and identify alternative solutions that can be applied in providing fair and pro-disabilities services. This research is a qualitative research utilizing interviews, observations and documentations. Interviews were conducted with related agencies namely the Department of Social Welfare, Department of Transportation, and the Department of Settlement and Regional Infrastructure as well as non-governmental organizations that have attention to disabled people such as SIGAB and NET. Secondary data were gathered from the documentation of the relevant agencies and the mass media as well as other literature sources such as books and journals. The results show that the provision of transportation services to meet the needs of disabled people is not optimal. Yogyakarta city has provided disabled friendly transportation facilities and Sleman regency also provides disabled-friendly pavements especially around the local government office complex. Meanwhile, 3 other regencies have not been optimal in the provision of facilities.
\end{abstract}

Keywords: public service, disabled, transportation, DIY 


\section{PENDAHULUAN}

Menjadi difabel ditengah masyarakat yang menganut paham 'normalisme', dimana semua sarana umum yang ada didesain khusus untuk 'orang normal' tanpa adanya fasilitas bagi difabel adalah sangat sulit. Masyarakat umum terkadang hanya memandang kasihan atau kurang peduli terhadap keberadaan kaum difabel. Bahkan, pusat rehabilitasi sekalipun dibangun untuk menjadikan mereka 'berbeda' dari orang lain. Dengan sebutan 'rehabilitasi', difabel disetarakan dengan para pecandu narkotika dan obat obatan terlarang sehingga mengalami kecacatan adalah suatu penyakit yang harus segera diobati. Akan tetapi, benarkah menjadi difabel adalah setara dengan dihinggapi sebuah penyakit? Seseorang yang memang diciptakan dengan satu 'perbedaan' oleh Sang Pencipta mungkin tidaklah membutuhkan rehabilitasi melainkan lebih membutuhkan persamaan derajat dan pengakuan dari lingkungannya.

Jumlah difabel di Indonesia pada tahun 2007 diprediksi sekitar 7,8 juta jiwa (Suharto, Edi, 2010). Sementara itu, jumlah difabel di Daerah Istimewa Yogyakarta (DIY) meningkat setelah bencana alam gempa bumi melanda tahun 2006. Sesuai data dari Dinas Sosial DIY tahun 2011, tercatat jumlah difabel di DIY pada tahun 2011 adalah 35. 264 jiwa. Sebuah angka yang sebenarnya relatif kecil dibandingkan jumlah penduduk Indonesia pada waktu itu berjumlah sekitar 220 juta jiwa.

Walaupun demikian selayaknya semangat pelayanan tidak dipengaruhi jumlah besar atau kecilnya pengguna layanan. Para difabel juga merupakan warga negara Republik Indonesia yang dalam Undang-Undang Dasar 1945 dijamin untuk memiliki kedudukan, hak, kewajiban, dan peran yang sama dengan warga negara lainnya. Kedudukan yang setara bagi seluruh warga negara adalah penting dalam rangka mewujudkan pembangunan nasional yang bertujuan mewujudkan masyarakat yang adil dan makmur berdasarkan Pancasila dan Undang-Undang Dasar 1945. Oleh karena itu, pemerintah sudah semesti- nya memberikan perhatian yang cukup kepada para difabel tersebut, termasuk dalam hal aksesibilitas pelayanan publik khususnya layanan transportasi darat.

Namun demikian, kenyataan di lapangan menunjukkan kondisi sebaliknya. Pelayanan sosial dan mobilitas para penyandang disabilitas kurang terpenuhi dengan layak dimana sebagian besar hambatan aksesibilitas masih banyak ditemui berupa hambatan arsitektural dan prosedural. Hal ini membuat kaum difabel kehilangan haknya dalam mendapatkan pelayanan yang setara dan bahkan untuk dikatakan baik.

Dalam hal aksesibilitas, ketersediaan sarana dan prasarana ramah difabel saat ini masih sangat terbatas di Indonesia pada umumnya dan Yogyakarta khususnya. Aksesibilitas difabel yang dijanjikan pemerintah dalam UU No 4 th 1997 pada prakteknya tetap saja belum mempermudah akses pergerakan mereka. Beberapa permasalahan seperti diungkapkan oleh Komisi Nasional Difabel berkaitan dengan mobilitas para difabel dapat terlihat pada:

1. Belum adanya perlindungan terhadap penyandang disabilitas pengguna kendaraan pribadi.

2. Penyeberangan masih menyulitkan penyandang disabilitas untuk melintas.

3. Kendaraan yang dimodifikasi kurang dipromosikan penggunaannya serta belum tersertifikasi aman.

4. Terminal dan halte sebagian besar belum didesain aksesibel atau dilengkapi dengan fasilitas aksesibilitas, seperti loket yang tinggi, emplasemen yang tidak sejajar dengan lantai bus, perbedaan lantai tanpa ram, dll.

5. Bus atau angkutan darat yang dipergunakan hingga saat ini sebagian besar belum menyediakan ruang khusus untuk kursi roda maupun tempat duduk yang diutamakan bagi penyandang disabilitas.

6. Rambu, marka dan informasi belum dapat diterima dan dipahami oleh semua orang.

7. Staf bus belum secara merata mengetahui dan mampu melayani pengguna penyandang disabilitas secara baik dan benar. 
Konsep pelayanan publik memiliki makna yang tidak jauh berbeda dengan konsep pelayanan umum atau pelayanan masyarakat. Oleh karena itu, penggunaan ketiga istilah tersebut saling dipertukarkan. Pelayanan publik menurut Undang-Undang Nomor 25 Tahun 2009 adalah kegiatan atau rangkaian kegiatan dalam rangka pemenuhan kebutuhan pelayanan sesuai dengan peraturan perundang-undangan bagi setiap warga negara dan penduduk atas barang, jasa, dan/atau pelayanan administratif yang disediakan oleh penyelenggara pelayanan publik. Pelayanan berfungsi sebagai sebuah sistem yang menyediakan apa yang dibutuhkan oleh masyarakat.

Keputusan Menteri Negara Pendayagunaan Aparatur Negara (Meneg PAN) Nomor 63/KEP/M.PAN/7/2003, memberikan pengertian pelayanan publik yaitu segala kegiatan pelayanan yang dilaksanakan oleh penyelenggara pelayanan publik sebagai upaya pemenuhan kebutuhan penerima pelayanan maupun pelaksanaan ketentuan peraturan perundang-undangan.

Pelayanan publik seharusnya memperhatikan asas-asas keadilan dan non diskriminatif, seperti tercantum dalam UU no 25/2009 tentang Pelayanan Publik. Menurut UU tersebut, pelayanan publik dikatakan baik jika memenuhi beberapa asas-asas sebagai berikut: a) Kepentingan Umum; b) Kepastian Hukum; c) Kesamaan Hak; d) Keseimbangan Hak dan Kewajiban; e) Keprofesionalan; f) Partisipatif; g) Persamaan perlakuan / tidak diskriminatif; h) Keterbukaan; i) Akuntabilitas; j) Fasilitas dan Perlakuan Khusus Bagi Kelompok Rentan; k) Ketepatan Waktu; l) Kecepatan Kemudahan dan Keterjangkauan.

Dengan demikian, jelas bahwa seharusnya pelayanan publik tetap memperhatikan keadilan dan ramah terhadap masyarakat berkebutuhan khusus seperti kaum difabel sebagai salah satu kelompok masyarakat rentan selain wanita dan anak-anak.

Istilah difabel berasal dari bahasa Inggris dengan asal kata different ability, yang bermakna manusia yang memiliki kemampuan yang berbeda. Istilah tersebut digunakan sebagai pengganti istilah penyandang cacat yang mempunyai nilai rasa negative dan terkesan diskriminatif. Istilah difabel didasarkan pada realita bahwa setiap manusia diciptakan berbeda. Sehingga yang ada sebenarnya hanyalah sebuah perbedaan bukan kecacatan ataupun ke'abnormal'an.

Sedangkan pengertian difabel menurut Undang-Undang No 4 tahun 1997 tentang Penyandang Cacat, adalah setiap orang yang mempunyai kelainan fisik dan/atau mental, yang dapat mengganggu atau merupakan rintangan dan hambatan baginya untuk melakukan aktivitas secara selayaknya, yang terdiri dari (a) penyandang cacat fisik, (b) penyandang cacat mental, dan (c) penyandang cacat fisik dan mental.

Difabel bukan hanya merupakan orang penyandang cacat sejak lahir melainkan juga korban bencana alam atau perang yang mendapatkan kecacatan ditengah-tengah hidupnya maupun para penderita penyakit yang mengalami gangguan melakukan aktivitas secara selayaknya baik gangguan fisik maupun mental. Beberapa jenis gangguan yang menyebabkan tergolongnya seseorang menjadi difabel adalah sebagai berikut : tuna netra (buta), tuna rungu, tuna wicara, tuna daksa, tuna grahita, dan tuna ganda (komplikasi antara dua atau lebih bentuk kecacatan).

Menurut data Susenas (Survey Sosial Ekonomi Nasional) tahun 2000, difabel di Indonesia mencapai 1,46 juta penduduk yaitu sekitar 0,74 \% dari total penduduk Indonesia (197 juta jiwa) pada tahun tersebut. Persentase difabel di daerah pedesaan sebesar 0,83 $\%$. Lebih tinggi dibanding dengan persentase di daerah perkotaan sebanyak 0,63 \%.

Sedangkan menurut Badan Kesehatan Dunia (WHO) belakangan memprediksikan bahwa satu dari 10 orang Indonesia adalah difabel. Meningkat dibandingkan hasil Quick survey WHO tahun 1979, yang menyimpulkan bahwa difabel di Indonesia mencapai 3,11 persen. Angka ini jauh lebih tinggi dibandingkan data SUSENAS. Sedangkan untuk Daerah Istimewa Yogyakarta tercata ada 35.264 difabel dari total jumlah penduduk 3.156,2 ribu jiwa. Penyandang difabel di DIY meningkat salah satunya karena terjadi gem- 
pa Yogyakarta pada tahun 2006 yang menimbulkan banyak korban mengalami kecacatan.

\section{Kebijakan-Kebijakan Mengenai Pemenu- han Hak Difabel di Indonesia}

Undang-undang No. 4 tahun 1997 menegaskan bahwa difabel merupakan bagian masyarakat Indonesia yang juga memiliki kedudukan, hak, kewajiban, dan peran yang sama. Mereka juga mempunyai hak dan kesempatan yang sama dalam segala aspek kehidupan dan penghidupan.

Selain UU No. 4/1997, pemerintah juga telah mengeluarkan Peraturan Pemerintah Nomor 43 Tahun 1998 tentang Upaya Peningkatan Kesejahteraan Sosial Penyandang Cacat. Pengaturan aksesibilitas pelayanan lebih lanjut bagi difabel secara lebih jelas dan gamblang diatur dalam Peraturan Pemerintah Nomor 43 Tahun 1998 tentang Upaya Peningkatan Kesejahteraan Sosial Penyandang Cacat. Difabel dalam PP ini dijamin kesamaan kesempatan dalam hak, kewajiban dan perannya sesuai dengan kemampuannya dalam kehidupan berbangsa dan bernegara. Agar difabel dapat berperan serta secara maksimal aksesibilitas bagi difabel dijamin.

Kebijakan terbaru berkaitan dengan difabel khususnya di Daerah Istimewa Yogyakarta adalah Peraturan Daerah No 4 tahun 2012 tentang Perlindungan dan Pemenuhan Hak-Hak Penyandang Disabilitas. Perda ini mencakup tentang penerapan pendidikan inklusi, pekerjaan kepada difabel (adanya penghargaan kepada perusahaan yang memberikan pekerjaan kepada difabel), kebijakan jaminan pembiayaan kesehatan daerah kepada difabel serta beberapa kebijakan layanan yang sudah mulai berpihak kepada difabel. Pasal 3 perda ini menegaskan bahwa Pemerintah Daerah DIY menjamin hak-hak kaum difabel meliputi hak dalam bidang pendidikan, ketenagakerjaan, kesehatan, sosial, seni, budaya, olah raga, politik, hukum, penanggulangan bencana, tempat tinggal, dan aksesibilitas.

\section{Aksesibilitas Difabel}

Undang-Undang No 4 Tahun 1997 tentang Penyandang Cacat Pasal 1 ayat 4 menyatakan 'Aksesibilitas' adalah kemudahan yang disediakan bagi penyandang cacat guna mewujudkan kesamaan kesempatan dalam segala aspek kehidupan dan penghidupan".

Setidaknya terdapat empat azas yang dapat menjamin kemudahan atau aksesibilitas difabel tersebut yang mutlak mestinya harus dipenuhi oleh pemerintah yakninya:

1. Azas kemudahan

2. Azas kegunaan

3. Azas keselamatan

4. Azas kemandirian

Sementara itu, aksesibiltas yang dijamin dalam PP No. 43 Tahun 1998 tentang Upaya Peningkatan Kesejahteraan Sosial Penyandang Cacat yaitu pengaturan aksesibilitas fisik dan non fisik. Aksesibilitas fisik diterapkan pada sarana dan prasarana umum seperti aksesibilitas pada bangunan umum, jalan umum, pertamanan dan pemakaman umum serta angkutan umum. Sedangkan aksesibilitas non fisik di terapkan pada pelayanan informasi dan pelayanan khusus.

\section{METODE}

Penelitian ini merupakan penelitian yang menggunakan pendekatan deskriptif kualitatif, dimana peneliti bertujuan untuk mendeskripsikan dan menganalisa penerapan pelayanan publik bidang transportasi yang diberikan kepada difabel di Daerah Istimewa Yogyakarta.

Data yang dibutuhkan dalam penelitian ini meliputi data primer dan data sekunder. Teknik analisis data yang digunakan dalam penelitian ini adalah teknik analisis kualitatif dengan triangulasi.

\section{HASIL DAN PEMBAHASAN}

\section{Jumlah Difabel di DIY}

Jumlah difabel di Daerah Istimewa Yogyakarta berdasarkan data Dinas Sosial tahun 2011 adalah 35. 264 jiwa seperti dalam Tabel 1 berikut ini. 
Tabel 1. Jumlah Difabel di DIY Tahun 2011

\begin{tabular}{llrr}
\hline \multicolumn{2}{c}{ No } & \multicolumn{1}{c}{ Kabupaten/ } & \multicolumn{2}{c}{ Jumlah } & Prosentase \\
& \multicolumn{1}{c}{ Kota } & 3.353 & 9,51 \\
1 & Kota Yogyakarta & 7.836 & 22,22 \\
2 & Bantul & 8.256 & 23,41 \\
3 & Sleman & 5.914 & 16,77 \\
4 & Kulon Progo & 9.905 & 28,09 \\
5 & Gunungkidul & 35.264 & 100,00 \\
\hline
\end{tabular}

Sumber: Dinas Sosial DIY

Dari tabel di atas, dapat dilihat bahwa jumlah difabel yang paling banyak adalah di Kabupaten Gunung Kidul yaitu mencapai 28,09 \% sementara jumlah difabel Kota Yogyakarta tergolong paling sedikit yaitu 9, 51\%. Prosentase jumlah difabel di DIY memang tergolong sedikit jika dibandingkan dengan total jumlah penduduk DIY yang berjumlah 3.487.325 jiwa pada tahun 2011 yaitu sekitar $1,01 \%$.

\section{Sarana dan Prasarana Transportasi Publik}

a. Data Kelas Jalan

Berdasarkan statusnya, jalan diperinci menjadi jalan negara, jalan provinsi, jalan kabupaten dan jalan desa. Jalan Provinsi sesuai dengan Kep.Gub. No.100/ Kep/ 2007 sedangkan jalan negara/nasional sesuai dengan Kep.Men Kimpraswil No.376/ KPTS/ M/ 2004. Keseluruhan panjang jalan di DIY adalah sepanjang $787.065 \mathrm{~km}$. Ruas jalan tersebut didominasi oleh jalan provinsi yaitu sepanjang $605.958 \mathrm{~km}$.

\section{Terminal di DIY}

Terminal berfungsi menghubungkan titik-titik utama di tiap-tiap wilayah DIY yang meliputi empat kabupaten, yaitu Bantul, Sleman, Kulon Progo dan Gunungkidul, serta Kota Yogyakarta. Di DIY terdapat 19 terminal yang tersebar di kota dan empat kabupaten. Sebagian besar terminal di DIY merupakan terminal tipe B yaitu terminal yang melayani angkutan dalam kota, sementara dua ter- minal yaitu terminal Giwangan, Wates dan Wonosari merupakan terminal dengan kategori A yang berfungsi untuk melayani angkutan antar kota dan antar provinsi.

\section{Angkutan Kota Dalam Provinsi}

Jumlah AKDP yang beroperasi memberikan pelayanan transportasi publik di DIY berjumlah 946 buah. AKDP tersebut masih menyediakan pelayanan yang bersifat konvensional dimana jadwal keberangkatan dan tempat menaikkan atau menurunkan penumpang yang tidak pasti. Hal ini kurang memberikan kenyamanan dan terkadang justru menimbulkan kemacetan lalu lintas karena armada AKDP tersebut menaikkan atau menurunkan penumpang di sembarang lokasi dan tidak di halte. Selain itu, kondisi bus juga tidak dapat memenuhi kebutuhan difabel karena space yang sempit dan ruangan dalam bus yang tidak flat/landai. Ketiadaan space khusus bagi kaum pengguna kursi roda juga menjadi kelemahan utama dari armada AKDP.

\section{Armada Bus Trans Jogja}

Trans Jogja adalah sebuah sistem transportasi bus cepat, murah dan ber-AC di seputar Kota Yogyakarta. Trans Jogja merupakan salah satu bagian dari program penerapan Bus Rapid Transit (BRT) yang dicanangkan Departemen Perhubungan. Sistem ini mulai dioperasikan pada awal bulan Maret 2008 oleh Dinas Perhubungan, Pemerintah DIY. Motto pelayanannya adalah "Aman, Nyaman, 
Andal, Terjangkau, dan Ramah lingkungan".

Pengelola Trans Jogja adalah PT Jogja Tugu Trans, sebagai wujud konsorsium empat koperasi pengelola transportasi umum kota dan pedesaan di DIY (Koperasi Pemuda Sleman, Kopata, Aspada, dan Puskopkar) dan Perum DAMRI. Sebagai komponen dari sistem transportasi terpadu bagi Kota Yogyakarta dan daerah-daerah pendukungnya, sistem ini menghubungkan enam titik penting moda perhubungan di sekitar kota:

1. Stasiun KA Jogjakarta Terminal Bus Giwangan sebagai pusat perhubungan jalur bis antar provinsi dan juga regional,

2. Terminal Angkutan Desa Terminal Condong Catur

3. Terminal Regional Jombor di sebelah utara kota,

4. Bandar Udara Adisucipto, dan Terminal Prambanan. Saat ini terdapat sekitar 54 armada bus dengan ukuran sedang untuk 34 tempat duduk sementara halte yang tersedia berjumlah 76 shelter. Bus Trans Jogja melayani transportasi publik di Kota Yogyakarta dari pukul 06.00 - 22.00 WIB.

Fasilitas khusus untuk difabel pada Trans Jogja yaitu berupa halte yang dilengkapi dengan tangga landai. Tangga ini diperuntukkan khusus untuk difabel terutama pengguna kursi roda. Pada beberapa shelter, halte bus Trans Jogja sudah dibuat landai seperti gambar 1 berikut.

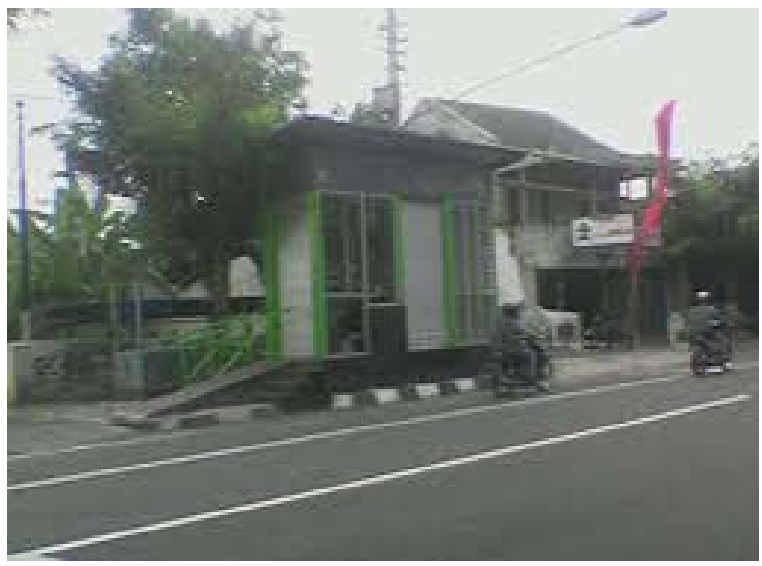

Gambar 1.

Lantai Halte Bus Trans Jogja yang Landai
Namun pada beberapa shelter, lantai pada halte bus masih cukup curam, kurang luas dan berbatasan langsung bangunan atau pepohonan sehingga dapat membahayakan bagi difabel.

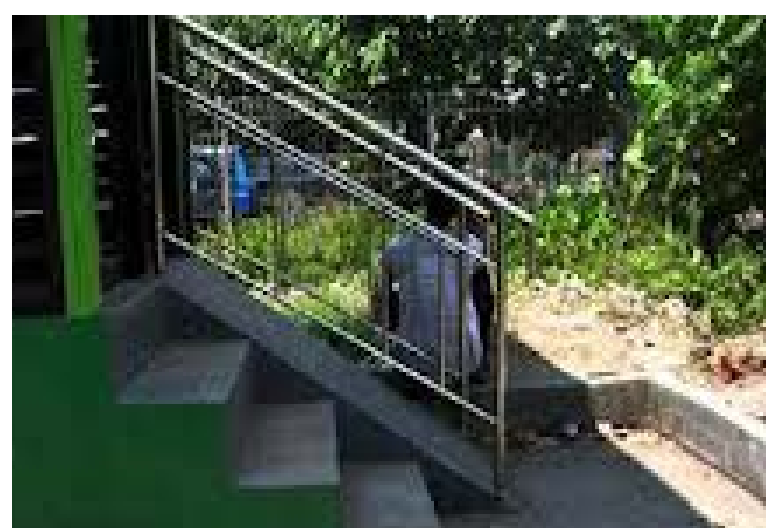

Gambar 2.

\section{Lantai Halte Bus Trans Jogja Masih Curam dan Kurang Luas}

Pada halte bus tersebut, terlihat bahwa pintu masuk masih terlalu sempit dan menyulitkan bagi difabel untuk keluar atau masuk. Sehingga luas pintu keluar/masuk halte belum memberikan kemudahan akses bagi pengguna kursi roda.

Untuk meningkatkan pelayanan transportasi di DIY, Dinas Perhubungan berencana untuk mengganti seluruh armada angkutan dalam kota dengan armada bus Trans Jogja mulai tahun 2015. Pada tahun 2015, Pemerintah Daerah DIY akan menerapkan rute baru dengan basic system Trans Jogja. Sehingga, seluruh bus kota akan dihentikan operasionalnya dan seluruh jalur di DIY diganti dengan Trans Jogja (Tribun Jogja, 8 November 2013).

\section{Angkutan Kereta Api, Udara, dan Laut}

Selain bus kota dan Trans Jogja, untuk transportasi darat terutama menuju luar DIY, masyarakat dapat menggunakan angkutan kereta api, udara dan laut. Saat ini, stasiun kereta api di Yogyakarta adalah Stasiun Tugu, Lempuyangan dan Wates di Kulon Progo. PT Kereta Api Indonesia cabang Yogyakarta melayani rute perjalanan ke beberapa provinsi 
di luar DIY yaitu Jawa Barat (Bandung dan DKI Jakarta), Jawa Tengah (Klaten dan Solo) dan Jawa Timur (Malang dan Surabaya).

Sementara itu untuk angkutan udara, DIY memiliki satu bandara internasional yaitu Bandara Internasional Adi Sucipto yang berlokasi di Kabupaten Sleman. Bandara ini melayani rute penerbangan domestik dan internasional ke beberapa wilayah di Indonesia dan luar negeri seperti Malaysia dan Singapura.

Untuk angkutan laut, DIY belum memiliki pelabuhan yang representatif untuk lalu lintas penumpang. Saat ini masyarakat di Yogyakarta harus menuju Pelabuhan Semarang atau Surabaya untuk menggunakan angkutan laut. Kapal dan perahu motor yang bersandar di pantai di wilayah DIY seperti Samas, Baron, Congot, Sermo, Depok, Ngrenehan dan pantai lain di Bantul, Kulon Progo serta Gunungkidul merupakan perahu nelayan untuk mencari ikan dan bukan perahu/kapal sebagai moda transportasi penumpang.

\section{Pelayanan Transportasi Publik di DIY Bus Trans Jogja}

Sampai saat ini, angkutan umum di DIY yang tergolong mulai ramah difabel adalah Bus Trans Jogja. Namun demikian, keberadaan Trans Jogja hanya menjangkau wilayah Kota Yogyakarta dan wilayah perbatasan dengan Kabupaten Bantul dan Sleman termasuk Bandara Adi Sucipto, dengan jumlah armada bus yang terbatas serta melayani rute yang terbatas pula. Fasilitas yang ada pada armada Bus Trans Jogja telah memberikan kemudahan bagi difabel dalam mengakses sarana perhubungan darat.

Sementara itu, pada armada bus Trans Jogja pintu masuk dan keluar bagi penumpang sudah didesain luas. Pintu yang luas pada armada bus ini memudahkan difabel khususnya tuna daksa untuk mengakses angkutan umum ini. Ruangan di dalam bus Trans Jogja juga berbeda dengan bus-bus lain. Desain ruangan bus Trans Jogja lebih luas dan lapang serta terdapat ruang (space) dan kursi khusus untuk pengguna kursi roda. Akan tetapi tidak semua armada bus Trans Jogja memiliki fasilitas khusus difabel ini.
Akan tetapi, upaya pelayanan tersebut ternyata dalam prakteknya tidak selalu memberikan kemudahan bagi difabel. Beberapa hal tetap saja kurang memperhatikan keberadaan para difabel sebagai konsumen. Difabel masih mengalami kesulitan dalam mengakses bus kota terutama bagi difabel pengguna kursi roda. Beberapa hambatan bagi difabel dalam penggunaan Transjogja adalah:

1. Adanya space yang terlalu lebar antara halte dan bis yang berhenti. Hal ini menyulitkan difabel baik tunanetra, pengguna kursi roda, maupun penderita semi ambulant (gangguan berjalan tapi tanpa menggunakan kursi Roda) naik maupun keluar bis.

2. Ramp pada pintu keluar/masuk halte terlalu curam, bahkan hampir mencapai 45 derajat. Hal ini tentunya akan menyulitkan bagi difabel berkursi roda maupun pihak keluarga yang mendorong kursi roda tersebut. Padahal berdasarkan standar fasilitas difabel, ramp idealnya mempunyai ukuran 1:12 hingga 1:15 antara tinggi dan alasnya.

3. Ramp yang ada sering berbatasan langsung dengan tiang bendera, taman, pohon, dan benda benda lain tanpa ada space bagi kursi roda hingga menyulitkan difabel naik maupun turun dari halte. Adanya perbedaan ketinggian yang cukup besar antara jalan dan halte Trans Jogja tanpa adanya ramp yang membatasi.

4. Perbedaan ketinggian dimana umumnya halte lebih tinggi $20-30 \mathrm{~cm}$ dibanding pintu bis. Hal ini menyulitkan difabel keluar dari bus.

5. Pintu masuk halte dilengkapi palang segitiga yang menyulitkan bagi pengguna kursi roda untuk mengakses.

6. Ruangan di dalam halte kurang luas, sehingga menyulitkan bagi pengguna kursi roda untuk melakukan rotasi.

7. Tidak ada petunjuk/ informasi /sinyal suara/alarm untuk difabel ruwi dan netra sehingga mereka salah turun atau salah jurusan.

8. Di dalam ruangan bus Trans Jogja pegangan terlalu tinggi, tidak ada pengait 
untuk kursi roda dan tidak ada pegangan di tempat duduk, sehingga kurang memberikan kenyamanan bagi kaum difabel.

9. Dalam menyikapi masalah masalah tersebut PT Jogja Tugu Trans mulai melakukan pembenahan dari segi desain dan posisi lahan yang digunakan sebagai halte trans. Beberapa perbaikan yang mulai dilakukan penyedia Trans Jogja adalah;

10. Halte didisain lebih menjorok di pintu keluar menuju bus bertujuan agar mempermudah difabel keluar masuk bus.

11. Ram yang tidak terlalu curam. Hal ini diharapkan mampu meringankan beban dalam mendorong kursi roda para difabel. Dalam hal ini kemiringan ram ideal sudah dapat dilihat pada halte Jl. KH Ahmad Dahlan.

12. Halte hendaknya dibangun dan menyisakan space lebih kurang $2 \mathrm{~m}$ di sebelah kanan dan sebelah kiri ram, agar ketika turun difabel tidak langsung berhadapan dengan taman, tiang bendera, dan tiang listrik sebagaimana pada halte Trans Jogja di Jl. KH Ahmad Dahlan, Gembiraloka dan Jl. Brigjen Katamso.

13. Penyediaan ram di batas antara jalan raya dan trotoar yang ada diatasnya.

14. Pintu halte dibangun sama tinggi dengan pintu bis dengan lebih teliti.

Salah satu wacana yang dilontarkan oleh Dinas Perhubungan DIY untuk meningkatkan pelayanan transportasi adalah mengganti seluruh armada AKDP lama (konvensional) dengan armada bus Trans Jogja (Tribun Jogja, 7 dan 8 November 2013). Dinas Perhubungan merencanakan bahwa mulai tahun 2015 bus Trans Jogja akan menambah rute pelayanan sebanyak 13 rute baru untuk menggantikan rute lama yang dilayani oleh AKDP. Berdasarkan wawancara dengan Dinas Perhubungan DIY, bus Trans Jogja juga akan semakin memperluas jangkauan pelayanan hingga mencakup Kabupaten Bantul (melayani arah dalam kota Bantul) dan Kabupaten Sleman (arah Pakem Kaliurang).

Selain itu, Trans Jogja juga akan mengadopsi sistem SMTS (Smart Mass Transit System) on bus, yaitu alat mesin tiket yang diletakkan di dalam bus.
Sebagaimana diberitakan di Republika (7/11/2013).

Dishubkominfo mengusulkan pengadaan 23 buah vending mesin yakni alat isi ulang tiket Trans Jogja. Setiap vending mesin harganya sekitar Rp 75 juta, sehingga apabila disetujui semua harganya sekitar Rp1,725 miliar. Saat ini di 54 bus Trans Jogja sudah ada SMTS on bus. Jadi seluruhnya ada sebanyak 123 SMTS on bus. Dengan sistem ini, pelayanan pada Trans Jogja diharapkan akan menjadi lebih baik dan memudahkan penumpang termasuk kaum difabel.

\section{Terminal Giwangan}

Selain Trans Jogja, Giwangan sebagai terminal terbesar di DI. Yogyakarta sendiri harusnya dibangun ramah difabel mengingat kevitalan sarana ini dalam menunjang kehidupan masyarakat. Idealnya, prasarana transportasi darat yang ramah difabel meliputi:

1. kondisi peturasan yang dapat dimanfaatkan difabel tanpa bantuan orang lain

2. pengadaan jalur khusus akses keluar masuk terminal

3. konstruksi tempat pemberhentian kendaraan umum yang sejajar dengan permukaan pintu masuk kendaraan umum

4. pemberian kemudahan dalam pembelian tiket

5. papan informasi tentang daftar trayek angkutan jalan yang dapat dibunyikan atau ditulis dengan huruf Braille

6. penyeberangan jalan yang dilengkapi pemberi isyarat bunyi bagi penyandang tuna netra

7. ruang tunggu yang dirancang secara khusus untuk difabel dan orang sakit.

Sedangkan pada kenyataannya terminal Giwangan belum menyediakan fasilitas yang ideal bagi difabel seperti aturan di atas, selain sepasang ramp dengan kemiringan yang sudah memadai 1 : 12 tanpa ada fasilitas yang lain.

Menurut keterangan bagian informasi terminal Giwangan, difabel yang ada khususnya tunadaksa, biasanya hanya digendong pihak keluarga di terminal tersebut karena memang minimnya fasilitas bagi difabel. Apa- 
lagi banyaknya jenjang tinggi ke lantai dua di terminal tersebut tanpa dilengkapi ramp alternatif. Hal ini seolah membuktikan bahwa kemudahan transportasi hanya milik kaum 'normal'.

Selain itu, toilet yang ada di tempat tersebut terbilang belum ramah difabel. Dengan lebar pintu masuk lebih kurang lima puluh sentimeter, kursi roda tentunya tidak akan dapat memasuki pintu tersebut. Selain itu, WC jongkok tanpa adanya pegangan (railing) biasanya juga menyusahkan bagi para difabel. Hal ini sangat kontras jika dibandingkan dengan toilet ramah difabel yang sudah disediakan di pusat-pusat perbelanjaan dengan disain ramah difabel yang sudah dikembangkan di Yogyakarta.

\section{Stasiun Kereta Api Tugu dan Lempuyan- gan}

Stasiun Tugu sebagai stasiun terbesar di DIY pun belum memberikan akses kemudahan bagi difabel. Pada pintu masuk utama, difabel pengguna kursi roda mengalami kesulitan untuk memasuki area stasiun karena harus menaiki tangga, tanpa ada jalan landai. Kendala lain muncul yaitu dari peron menuju kereta yang tidak aksesibel khususnya bagi pengguna kursi roda. Selain itu, di dalam kereta api pun kamar mandi tidak dapat diakses oleh pengguna kursi roda karena terlalu sempit.

Beberapa waktu yang lalu, seorang penyandang difabel mengadukan PT KAI khususnya Stasiun Tugu kepada Ombudsman Republik Indonesia (ORI) karena kurang menyediakan fasilitas yang ramah difabel. Menurutnya PT KAI belum mengakomodasi permintaan pelayanan non fisik bagi kaum difabel, misalnya arahan menuju loket bagi difabel. Petugas khusus yang berfungsi melayanani dan membantu difabel pun menurutnya belum ada. Namun demikian, beberapa fasilitas umum seperti toilet di dalam stasiun telah memberikan kemudahan bagi difabel dengan penyediaan toilet khusus bagi difabel.

\section{Bandara Adi Sucipto}

Bandara Adi Sucipto sebagai bandara in- ternasional di Yogyakarta kurang memberikan kemudahan akses bagi difabel. Tempat parkir bandara yang relatif jauh memungkinkan munculnya sejumlah masalah bagi komunitas difabel. Selain itu, kondisi lantai yang licin juga akan membahayakan bagi difabel. Masalah lain muncul dari ruang tunggu (terminal keberangkatan) menuju pesawat di mana fasilitas belalai gajah kurang mencukupi jumlahnya sehingga terkadang para difabel mengalami kesulitan saat naik ke dalam pesawat.

Sementara itu kamar mandi khusus difabel sudah ada, akan tetapi sering digunakan oleh non difabel. Loket boarding pass dinilai terlalu tinggi untuk pengguna kursi roda sehingga mereka mengalami kesulitan untuk mengangkat tas bawaan. Fasilitas kursi roda yang tersedia di bandara kurang menjamin keamanan difabel karena banyak yang sudah rusak.

\section{Kapal}

Sebagai moda transportasi laut, kapal laut belum memberikan kemudahan akses bagi difabel. Kendala yang mungkin dihadapi oleh difabel meliputi tangga naik kapal yang tinggi dan curam serta tidak aksesibel serta ketiadaan toilet yang mampu memenuhi kebutuhan difabel yaitu ruangan toilet yang luas dan ada pegangan bagi mereka. Sehingga sebagian besar fasilitas dalam kapal tidak aksesibel bagi kaum difabel.

\section{Sepeda Motor Bagi Difabel}

Kepolisian Daerah DIY mengeluarkan Surat Nomor B/4965/XII/2008/Ditlantas ditujukan kepada Kepala Poltabes/Kepala Polres se-DIY perihal Pembuatan Surat Izin Mengemudi (SIM) untuk Penyandang Cacat pada10 Desember 2008 lalu. Ada tiga hal pokok yang harus dilaksanakan oleh Poltabes/Polres:

1. Tidak ada diskriminasi dalam pengurusan SIM antara difabel dan nondifabel.

2. Memberikan pelayanan dan menyediakan sarana dan prasarana bagi difabel yang dapat mempermudah difabel mengurus SIM.

3. Difabel diperbolehkan melakukan modifikasi kendaraan bermotor dengan ber- 
pedoman pada ketentuan yang ada.

Peraturan ini memang baru berlaku di Kota Yogyakarta dan belum dilasanakan di kabupaten lain di wilayah DIY.

Dalam pengurusan SIM bagi difabel seharusnya mereka mendapatkan SIM D khusus bagi difabel. Akan tetapi, pada kenyataannya, para difabel belum mendapatkan SIM D tersebut tetapi mereka mendapatkan SIM C yang disetarakan dengan pengendara sepeda motor pada umumnya. Alasan dari pihak berwenang adalah karena ketiadaan persediaan SIM D di instansi berwenang.

Dengan demikian dapat dikatakan bahwa dalam hal menjamin keamanan berkendaraan three wheels bagi difabel kurang mendapatkan perhatian dari pihak berwenang. Pengadaan kendaraan tersebut pun masih tanpa ada kebijakan yang menjamin keamanan bagi pemakainya seperti bengkel atau perusahaan khusus tersertifikasi karena modifikasi three wheels diserahkan kepada pemiliknya.

\section{Marka Rambu}

Saat ini sebagian besar marka rambu lalu lintas di DIY kurang memberikan petunjuk bagi kaum difabel. Pada traffic light, sinyal suara yang sangat berguna untuk memberikan informasi tentang lalu lintas kendaraan bagi tuna netra tidak ada. Selain itu, banyak polisi tidur yang dibangun di beberapa ruas jalan menyusahkan pengguna kursi roda dan motor modifikasi. Namun, ada satu marka rambu yang disediakan oleh Dinas Perhubungan untuk difabel khususnya tuna netra adalah di kawasan Malioboro. Marka rambu tersebut digunakan untuk penyeberangan kaum tuna netra yaitu dengan memencet tombol yang menempel pada tiang lampu lalu lintas tersebut.

\section{Trotoar}

Fasilitas yang ada pada trotoar jalan yaitu berupa trotoar yang dilengkapi dengan guide atau biasa disebut dengan track atau guiding block. Guiding block ini berfungsi untuk membantu para penyandang tuna netra dalam memudahkan mengakses jalan dengan pembuatan block yang berbeda dengan block trotoar yang lain. Akan tetapi, trotoar tersebut menjadi tidak dapat berfungsi maksimal bagi para difabel karena alih fungsi trotoar menjadi lahan parkir atau tertutupi pedagang kaki lima seperti yang terjadi di Jalan Malioboro.

Upaya yang dilakukan Dinas Keamanan dan Ketertiban Kota Yogyakarta untuk mengatasi penyalahgunaan trotoar adalah dengan melakukan penertiban dan pelarangan pedagang kaki lima untuk berjualan di trotoar. Selain itu Dinas ini juga berkerja sama dengan Dinas Perhubungan; Pemukiman dan Prasarana Wilayah.

Namun kenyataannya, pedagang kaki lima masih saja berjualan pada areal trotoar bertrack khusus. Alasan mereka adalah bahwa berjualan di trotoar untuk memenuhi kebutuhan hidup. Kerja sama yang terjalin antara Dinas Perhubungan dengan dinas-dinas terkait seperti Kimpraswil, Satpol PP dan Dinsos dalam pengawasan pemakaian trotoar masih belum efektif. Kadang kala yang terjadi adalah, Dinas Kimpraswil telah membuat trotoar ramah difabel tetapi beberapa bulan berikutnya trotoar tersebut dibongkar untuk memperbaiki saluran atau kegiatan lain dan tidak dikembalikan seperti sedia kala. Alhasil pembangunan trotoar ramah difabel pun kurang berfungsi dengan maksimal.

LSM dan para seniman pernah melakukan aksi demonstrasi sebagai upaya untuk mengkritik alih fungsi trotoar tersebut. Dalam kegiatan tersebut LSM SAPDA bekerja sama dengan seniman Jogja dan home schooling untuk mengadakan kegiatan aksi namun berupa hiburan di TBY melalui pantomim yang menggambarkan pada ketersediaan trotoar yang tidak aksesibel bagi difabel.

Sementara itu, di Kabupaten Slemen, trotoar yang dibangun dengan memperhatikan kebutuhan difabel sudah mulai dikembangkan berupa garden line pada trotoar yang merupakan sarana khusus bagi tunanetra. Penyediaan garden line ini dimulai tahun 2011. Garden line ini berupa keramik berwarna kuning dengan motif garis-garis timbul. Sarana tersebut baru bisa ditemukan di daerah sekitar Kantor Dinas Sosial hingga Bappeda Kab. Sleman. 
Pelayanan transportasi publik yang tersedia di Kota Yogyakarta tergolong sudah mulai mengadopsi kebutuhan difabel meskipun belum optimal. Di kabupaten Sleman, pembangunan trotoar ramah difabel merupakan salah satu rintisan pemberian pelayanan perhubungan untuk memenuhi kebutuhan difabel. Namun demikian tiga kabupaten di wilayah DIY yaitu Bantul, Gunungkidul dan Kulon Progo sama sekali belum menyediakan sarana prasarana transportasi yang ramah difabel. Selama ini pemerintah daerah di tiga kabupaten tersebut sedang memperbaiki sarana prasarana transportasi umum seperti pelebaran dan pengaspalan jalan, peningkatan pelayanan bus AKDP, serta himbauan untuk membangun sarana gedung perkantoran yang ramah difabel, seperti adanya jalan landai dan toilet khusus difabel.

Dalam wawancara dengan dinas terkait di Bantul, Kulon Progo dan Gunung Kidul,, mereka mengakui bahwa baru Pemerintah Kota Yogyakarta yang mengimplementasikan kebijakan kemudahan aksesibilitas perhubungan bagi difabel. Ke depan dinas-dinas di kabupaten tersebut juga berencana untuk melaksanakan kebijakan yang telah ada seperti Perda Prov. DIY No.4 tahun 2012 tentang Perlindungan dan Pemenuhan Hak-hak Disabilitas. Selama ini mereka memang belum concern terhadap permasalahan difabel selain karena keterbatasan dana juga karena ketiadaan kritik dari kaum difabel yang disampaikan kepada pemerintah kabupaten atau dinas yang berwenang.

\section{Alternatif Solusi Penyediaan Pelayanan Transportasi Ramah Difabel}

Kaum difabel juga merupakan warga negara Indonesia yang berhak atas penyediaan pelayanan transportasi yang aksesibel dan adil. Saat ini, pemerintah DIY telah mengeluarkan berbagai produk kebijakan untuk melindungi kebutuhan difabel seperti mengadopsi UU No 25 tahun 2009 tentang Pelayanan Publik, Undang-Undang Nomor 19 Tahun 2011 tentang Pengesahan Convention on The Right of Persons with Disabilities (Konvensi Mengenai Hak-Hak Penyandang Disabilitas), Perda No.4 tahun 2012 tentang tentang Perlindungan dan Pemenuhan Hakhak Disabilitas serta Pergub DIY No. 31 tahun 2013 tentang Komite Perlindungan dan Pemenuhan Hak-hak Disabilitas.

Untuk mewujudkan pelayanan transportasi yang adil dan ramah difabel di DIY, terdapat beberapa solusi yang dapat diambil oleh pemerintah daerah dengan bekerja sama dengan LSM, swasta ataupun stakeholders yang lebih luas. Alternatif solusi tersebut adalah sebagai berikut:

1. Pemerintah, LSM, swasta, penyandang disabilitas dan stakeholders meningkatkan kerja sama dalam penyadaran hakhak difabel melalui banyak media seperti, diskusi, workshop, media massa ataupun fasilitas web.

2. Penyedia layanan transportasi publik meningkatkan kuantitas dan kualitas pelayanan transportasi yang aksesibel dan ramah difabel. Peningkatan jenis pelayanan transportasi meliputi penyediaan taksi khusus bagi difabel, parkir motor dan mobil khusus bagi penyandang disabilitas, pemberian tiket gratis untuk naik bus Trans Jogja bagi tuna netra dan penyandang kecacatan ganda seperti yang diterapkan di negara-negara maju (South Australian Government Policy, 2013).

3. Pemerintah di masa yang akan datang dapat mengadopsi pelayanan transportasi yang telah dikembangkan di negara maju seperti Australia (Currie and Allen, 2010):

4. Bantuan untuk menyediakan kendaraan pribadi karena tidak dapat mengakses kendaraan umu terutama bagi para pekerja sosial dan sukarelawan..

5. Peningkatan anggaran untuk penyediaan sarana prasarana transportasi publik dengan menggandeng pihak swasta / pihak donor baik dari dalam negeri maupun luar negeri.

6. Penyediaan bantuan taksi khusus difabel. Bantuan dapat berupa subsidi atau potongan harga khusus bagi difabel.

7. Peningkatan transportasi milik komunitas untuk penyediaan pelayanan transportasi khusus bagi kaum difabel.

8. Perluasan jaringan atau network dalam 
penyediaan sarana prasarana transportasi publik.

\section{SIMPULAN}

Hingga saat ini di DIY, Pemerintah Kota Yogyakarta menjadi pelopor dalam penyediaan sarana prasarana transportasi yang aksesibel bagi difabel. Pelayanan ramah difabel tersebut, sayangnya, belum diimplementasikan oleh empat kabupaten di wilayah DIY. Adapun penyediaan pelayanan transportasi pro difabel di Kota Yogyakarta terlihat pada penyediaan bus trans Jogja dan halte khusus bis Trans Jogja yang berupaya memenuhi kebutuhan bagi difabel.Selain itu, beberapa ruas trotoar di jalan utama Kota Yogyakarta yaitu di Jalan Malioboro dan Jalan Taman Siswa juga telah dibangun ramah difabel. Namun demikian masih terdapat sejumlah permasalahan berkaitan dengan penyediaaan sarana prasarana transportasi tersebut:

1. Ram pada halte trans Jogja masih terlalu curam, kurang lebar dan berbatasan langsung dengan pohon atau objek lain sehingga membahayakan.

2. Masih ada space yang lebar antara halte dan bus

3. Kekurangpahaman awak angkutan akan kebutuhan difabel

4. Penyalahgunaan trotoar untuk areal parkir dan berjualan

5. Kerja sama antar instansi pemerintah yang kurang padu

6. Sarana prasarana pada stasiun, bandara dan kapal belum ramah difabel seperti banyaknya space curam yang membahayakan kaum difabel.

Kekurangtegasan pemerintah dalam mengimplementasikan dan memberikan sangsi terhadap pelanggar kebijakan, misalnya alih fungsi trotoar untuk parkir dan PKL.

Berkaitan dengan permasalahan yang dihadapi dalam penyediaan transportasi tersebut, terdapat beberapa alternatif solusi yang dapat diambil oleh pemerintah DIY, antara lain:

1. Peningkatan kesadaran (awareness) masyarakat akan kebutuhan difabel khususnya dalam bidang transportasi.

2. Peningkatan kuantitas dan kualitas pelayanan transportasi pro difabel dengan kerja sama yang padu antar instansi dalam pemerintah dengan swasta, LSM serta lembaga donor seperti USAID dan AUSAID.

3. Peningkatan jaringan dan network untuk prnyediaaan trasnportasi pro difabel.

\section{UCAPAN TERIMA KASIH}

Kami ucapkan terima kasih kepada semua pihak yang membantu penelitian ini. Tidak lupa kami juga mengucapkan terima kasih kepada redaktur yang memuat hasil penelitian ini.

\section{DAFTAR PUSTAKA}

Currie, Graham dan Allen, John, 2010, Australians With Disabilities Transport Disadvantage And Disability, Australai, Monash University.

Harian Tribun Jogja edisi 7,8, 9 dan 10 November 2013

Harian Republika edisi 8 November 2013

Peraturan Daerah Propivinsi DIY No 4 tahun 2012 tentang Perlindungan dan Pemenuhan Hak-Hak Penyandang Disabilitas.

Peraturan Gubernur DIY No.31 Tahun 2013 tentang Komite Perlindungan dan Pemenuhan Hak-Hak Disabilitas.

Peraturan Pemerintah Nomor 43 Tahun 1998 tentang Upaya Peningkatan Kesejahteraan Sosial Penyandang Cacat.

Suharto, Edi, 2008, Penerapan Kebijakan Publikbagi Masyarakat dengan Kebutuhan Khusus, Pengalaman Kementerian Sosial, makalah disampaikan pada diskusi terbatas Pusat Kajian Manajemen Pelayanan LAN RI di Hotel Sahira Bogor, 9-10 Oktober 2008.

Undang-Undang Nomor 4 Tahun 1997 tentang Penyandang Cacat.

Undang-Undang Nomor 25 Tahun 2009 tentang Pelayanan Publik 